\title{
Socio-economic Empowerment of Dairy Farmers through Dairy Cooperatives with Special Reference to Mehsana District
}

\author{
Maulik C. Prajapati \\ Assistant Professor, Dairy Business Management Department, SMC College of Dairy Science, Anand Agricultural University, Anand, \\ Gujarat, India
}

Corresponding author: maulik8180@gmail.com (ORCID ID: 0000-0002-1614-2586)

Received: 08-03-2021

Revised: 09-04-2021

Accepted: 05-06-2021

\begin{abstract}
Dairy cooperatives provide sustainable livelihood to millions of households in rural Gujarat. Largely, rural people engage in the farm as well as non-farming activities like animal husbandry and Dairy. The study has analysed the socio-economic Empowerment of member Dairy Farmers through dairy Cooperatives. The primary data have been collected from 200 Members Dairy Farmers in the Mehsana district by convenience sampling method. Google form was used for data collection. The tools used for the analysis were simple percentage methods. From the study, it can be concluded that Dairy Cooperative playing an important role in the social and economic development of member dairy farmers of the Mehsana District. Member Dairy Farmers contribute significantly to Dairy in Gujarat, their participation in dairy farming is considered as an important tool for alleviating poverty and enhancing the quality of life of the rural community.
\end{abstract}

\section{HIGHLIGHTS}

(0 A majority of the Dairy Farmers are involved in Animal Husbandry and Agriculture activity.

0 Most of the dairy farmers are literate and earning a good income from dairying activities.

( The economic status of Dairy farmers increased significantly after joining Dairy Cooperative.

( The social status of Dairy farmers enhanced due to the Dairy Cooperative.

Keywords: Dairy cooperatives, animal husbandry, socio-economic

India continues to be the largest milk producer in the world with an annual production of 188 million tonnes recorded in 2018-19. India is the leading milkproducing country in the world since the year 1997 and it contributes to around $20 \%$ of the world Milk has the highest value in the Indian agriculture and food sector, more than the combined value of wheat and rice. Milk contributes close to one-third of the gross income of rural households. The livestock sector contributes to $4 \%$ of India's GDP and the dairy sector engrafts the majority of the share. In short Indian Dairy Sector plays a very important role in the Indian Economy. It is an undeniable fact that the role and contribution of Dairy Professionals in the growth and development of the Indian Dairy sector are enormous.

How to cite this article: Prajapati, M.C. (2021). Socio-economic Empowerment of Dairy Farmers through Dairy Cooperatives with Special Reference to Mehsana District. Int. J. Soc. Sci., 10(02): 187-190.

Source of Support: None; Conflict of Interest: None (2) 9 
India is a densely populated country and the majority of people live in the village areas. The majority of the population in India lives in villages where agriculture is the main economic activity. Besides crop farming, the domestication of animals has been an integral part of the farming system from time immemorial. It is a centuriesold tradition for millions of Indian rural households (Khan et al. 2011).

The majority of them are involved in agriculture and animal husbandry activities. The agriculture, being only seasonal, the dairy industry provides off-season work to the people who are engaged in dairy-related activities, steady income and keeps them employed throughout the year. The livestock sector has been playing a significant role in the Indian economy and is a vital subsector of Indian agriculture.

Milk cooperatives are an integral part of the milk marketing and dairy development program in India. Village milk cooperatives successfully supporting the socioeconomic status of Dairy farmers after agriculture. In Gujarat state cooperative dairy movement running successfully through village milk cooperative societies structure. These village milk cooperative societies have a tremendous influence on the socioeconomic status of members. Members get sufficient income and generate employment for all members of the family and by better marketing facilities for their produce Dairy Farmers play an important role in the economic and social development of societies

\section{Objectives of the Study}

The present research study was carried out with the following specific objectives:

1. To study demographic characteristics of Dairy farmers.

2. To study Socio Economic Empowerment of Dairy Farmers.

\section{Scope of the study}

The present research work has been taken up to study socio economic development of member dairy farmers through dairy cooperative in Mehsana District.

\section{RESEARCH METHODOLOGY}

\section{Data}

This study is based on primary as well as secondary data. The primary data collected through a structured questionnaire and the secondary data collected through the study of published books, reports, periodicals, dissertations, articles, dailies, brochures, and Annual reports.

\section{Sampling method}

By employing the convenience sampling method data were collected from 200 respondents from village dairy co-operatives of Mehsana district.

\section{DATA ANALYSIS, RESULT AND DISCUSSION}

\section{Demographic factors}

The following paragraphs discuss demographic factors of select Member Dairy Farmers in Mehsana district.

Table 1: Gender of Dairy Farmers

\begin{tabular}{lll}
\hline Gender & Respondents & Percentage \\
\hline Male & 127 & 63.5 \\
Female & 73 & 36.5 \\
\hline Total & $\mathbf{2 0 0}$ & $\mathbf{1 0 0}$ \\
\hline
\end{tabular}

Out of 200 Member Dairy Farmers, 127 (63.5\%) are male and the rest $73(36.5 \%)$ are female. Thus, a majority of the Member Dairy Farmers are male.

Table 2: Educational Qualification

\begin{tabular}{lll}
\hline Educational Qualification & Respondents & Percentage \\
\hline Primary (Standard 1 to Standard 7) & 39 & 19.5 \\
$\begin{array}{l}\text { Secondary (Standard 8 to Standard } \\
\text { 10) }\end{array}$ & 103 & 51.5 \\
$\begin{array}{l}\text { Higher Secondary (Standard 11 to } \\
\text { Standard 12) }\end{array}$ & 42 & 21 \\
Graduate & 10 & 5 \\
Post Graduate & 4 & 2 \\
Illiterates & 2 & 1 \\
\hline Total & $\mathbf{2 0 0}$ & $\mathbf{1 0 0}$ \\
\hline
\end{tabular}


Out of 200 respondents, 39 (19.5\%) Member Dairy Farmers have Primary (Standard 1 to Standard 7) qualification, $103(51.5 \%)$ have Secondary (Standard 8 to Standard 10) educational qualification; 42 (21\%) have Higher Secondary (Standard 11 to Standard 12) qualification, $10(5 \%)$ graduate educational qualification, $4(2 \%)$ were Post Graduate the rest 2(1\%) are illiterate. Thus, most of the Member Dairy Farmers have Secondary and Higher Secondary qualifications.

Table 3: Type of Family

\begin{tabular}{lll}
\hline Type of Family & Respondents & Percentage \\
\hline Joint & 129 & 64.5 \\
Nuclear & 71 & 35.5 \\
Total & 200 & 100 \\
\hline
\end{tabular}

Out of 200 respondents, 129 (64.5\%) Member Dairy Farmers belong to joint family and the remaining $71(35.5 \%)$ to nuclear family. Thus, a majority of the Member Dairy Farmers belong to Joint Family.

Table 4: Occupation

\begin{tabular}{lll}
\hline Occupation & Respondents & Percentage \\
\hline Only dairying/Animal husbandry & 10 & 5 \\
Animal Husbandry + Agriculture & 174 & 87 \\
Animal Husbandry + service & 6 & 3 \\
Animal Husbandry + Agriculture + & 2 & 1 \\
service & & \\
Animal Husbandry + Any other & 8 & 4 \\
business & & \\
Other & 0 & 0 \\
Total & $\mathbf{2 0 0}$ & $\mathbf{1 0 0}$ \\
\hline
\end{tabular}

In regard to occupation, $174(87 \%)$ Member Dairy Farmers are involved in Animal Husbandry and Agriculture business, $10(5 \%)$ are involved in only dairying/Animal husbandry activities while only 6 $(3 \%)$ are involved in Animal Husbandry and any other business.

Table 5: Monthly Income

\begin{tabular}{lll}
\hline Monthly Income & Respondents & Percentage \\
\hline$\leq ₹ 10000$ & 3 & 1.5 \\
₹ 10001 to ₹ 20000 & 81 & 40.5 \\
₹ 20001 to ₹ 50000 & 101 & 50.5 \\
Above ₹ 50000 & 15 & 7.5 \\
\hline Total & $\mathbf{1 0 0}$ & $\mathbf{1 0 0}$ \\
\hline
\end{tabular}

Thus, a majority of the Member Dairy Farmers are involved in Animal Husbandry and Agriculture activity.

The monthly income of 3 (1.5\%) Member Dairy Farmers are less than 10000, that of 81 (40.5\%) from ₹ 10001 to ₹ 20000 and that of 101 (50.5\%) from 20001 to ₹ 50000 . Thus, the monthly income of most of the Member Dairy Farmers from 1000 to 50000 .

Table 6: Animal Holding

\begin{tabular}{lll}
\hline Animal Holding & Respondents & Percentage \\
\hline$\leq 2$ & 8 & 4 \\
$3-4$ & 83 & 41.5 \\
$5-6$ & 94 & 47 \\
$7-8$ & 9 & 4.5 \\
$>8$ & 6 & 3 \\
\hline Total & $\mathbf{2 0 0}$ & $\mathbf{1 0 0}$ \\
\hline
\end{tabular}

Above table indicate that 8 (4\%) Member Dairy Farmers had less than 2 animals, 83 (41.5\%) had 3-4 animals. 94 $(47 \%)$ had 5-6 animals, 9 (4.5\%) had 7-8 animals while 6 (3\%) Member Dairy Farmers had more than 8 animals.

Table 7: Opinion of Respondents on their Economic Empowerment

\begin{tabular}{|c|c|c|c|c|c|c|}
\hline 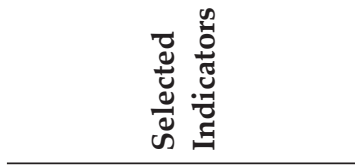 & 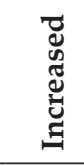 & $0^{0}$ & 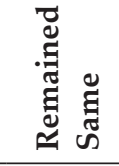 & $0^{0}$ & 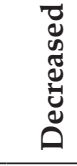 & $0^{\circ}$ \\
\hline $\begin{array}{l}\text { Purchase of immovable } \\
\text { asset in own name }\end{array}$ & 137 & 68.5 & 52 & 26 & 11 & 5.5 \\
\hline $\begin{array}{l}\text { Access to family } \\
\text { resources }\end{array}$ & 102 & 51 & 63 & 31.5 & 35 & 17.5 \\
\hline Personal Income & 165 & 82.5 & 25 & 12.5 & 10 & 5 \\
\hline Savings account in bank & 193 & 96.5 & 5 & 2.5 & 2 & 1 \\
\hline Personal insurance & 156 & 78 & 31 & 15.5 & 13 & 6.5 \\
\hline $\begin{array}{l}\text { Confidence in financial } \\
\text { transactions }\end{array}$ & 167 & 83.5 & 26 & 13 & 7 & 3.5 \\
\hline
\end{tabular}

Out of the total 200 respondents of this study, 68.5 percent said that purchase of immovable property asset increased, 51 percent were having access to family resources of their families, 82.5 percent said that they have increased their personal Income, 96.5 percent informed that they were having savings account in banks, and 78 
percent said that they were having personal insurance to meet future demands and 83.5 percent were having Confidence in financial transactions.

Table 8: Opinion of Respondents on Selected Indicators on their Social Empowerment

\begin{tabular}{|c|c|c|c|c|c|c|}
\hline 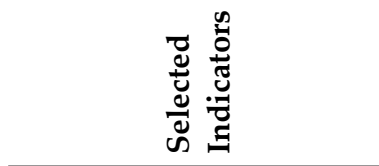 & 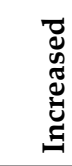 & $0^{0}$ & 莺 & $0^{0}$ & 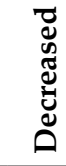 & $0^{0}$ \\
\hline $\begin{array}{l}\text { Respect from family } \\
\text { members }\end{array}$ & 176 & 88 & 16 & 8 & 8 & 4 \\
\hline Respect from relatives & 162 & 81 & 27 & 13.5 & 11 & 5.5 \\
\hline Leadership qualities & 106 & 53 & 56 & 28 & 38 & 19 \\
\hline $\begin{array}{l}\text { Individually attending } \\
\text { family functions of } \\
\text { relatives }\end{array}$ & 128 & 64 & 55 & 27.5 & 17 & 8.5 \\
\hline Communication Abilities & 193 & 96.5 & 5 & 2.5 & 2 & 1 \\
\hline $\begin{array}{l}\text { Awareness to Govt. } \\
\text { Schemes }\end{array}$ & 184 & 92 & 13 & 6.5 & 3 & 1.5 \\
\hline Decision making in family & 135 & 67.5 & 54 & 27 & 4 & 2 \\
\hline
\end{tabular}

Out of the total 200 respondents interviewed for this study, 88 percent said respect from their family members increased, only 4 percent said that respect from their family members decreased. The majority $(81 \%)$ of respondents opinioned that they were getting respect from their relatives. Around 64 percent said that they were individually attending family functions relatives were increased while 5.5 percent said that they were not individually attending family functions relatives. Around 96.5 percent of respondents said their communication skills improved after joining the Dairy Cooperatives, 92 percent said due to the joining of Dairy Cooperatives awareness regarding Government Schemes were also increased.

\section{CONCLUSION}

The dairy cooperative is playing a significant role in the economic and social empowerment of member dairy farmers. From the study, we found that after joining the dairy cooperatives personal income, Purchase of immovable assets, Access to family resources, personal insurance, and confidence in the financial transaction are increased. Same way after joining the dairy cooperative
Respect from family members, Respect from relatives, Leadership qualities, Communication Abilities, and Awareness to Govt. Schemes are also increased. It shows dairy cooperatives playing important role in the social and economic development of dairy farmers in Mehsana. The dairy cooperative is also helping dairy farmers to promote to create awareness in health, sanitation, and education to the farmers.

\section{ACKNOWLEDGEMENTS}

The author sincerely acknowledge the support of Indian Council of Social Science Research (ICSSR), Ministry of Human Resource Development (MHRD) Impactful Policy Research in Social Science (IMPRESS scheme) Government of India, Anand Agricultural University Anand, SMC College of Dairy Science, Dairy Business Management Department and Mr. Alpesh Jatapara (Research Assistant) for data collection and analysis and the support of all the respondents in this study.

\section{REFERENCES}

Chayal, K., Daaka, B.L. and Suwalka, R.L. 2009. Analysis of role performed by farm women in dairy farming. Indian J. Dairy Sci., 62: 491-494.

Khan, N., Salman, M.S. and Rehman, A. 2011. Livestock husbandry in rural urban fringe of Alighar Town: Environmental Sustainability. Adv. J. Geographic World, 1(2): 18-27.

Lathiya, A. and Parmar, G. 2017. Social and Economic Empowerment of Rural Women by Cooperative: Evidence from Dang District (Gujarat). Int. J. Business and Admin. Res. Rev., 2(18): 8-11.

Meera, M., Krishne, G. 2013. Towards Economic Empowerment. Study of Rural Women in Dairy Cooperatives of Heggada Devana Kote Taluk in Mysore District, J. Media and Soc. Dev., 3(5): 17-36.

Prajapati, M.C. 2021. A Study on The Awareness of SocioEconomic Upliftment Schemes Provided To Member Dairy Farmers by Dairy Cooperatives. Int. J. Edu. Sci. Res. (IJESR), 11(1): 79-84.

Rathod, N. and Ganga, D. 2019. SHG: a reliable expedient for socio-economic empowerment of tribal women farmers in Gujarat. Gujarat J. Exten. Edu., 30(1): 27-33.

Selvamani, P. 2017. Towards empowerment: An empirical study on rural women in dairy cooperatives. Int. J. Adv. Res. Deve., 2(4): 24-28.

Thaker, N.M., Bhatt, J.D. and Trivedi, S.M. 2020. Women Empowerment through Milk Producers Cooperative Societies. Gujarat J. Exten. Edu., 31(2): 84-91. 